Kalamatika: Jurnal Pendidikan Matematika

Volume 6, No. 1, April 2021, pages 15-30

\title{
PERCEPTIONS OF MATHEMATICS EDUCATIONSTUDENTS TOWARD E-LEARNING DURING THE COVID-19 PANDEMIC
}

\author{
Julia Noviani ${ }^{1}$ \\ ${ }^{1}$ IAIN Takengon, Jln. Aman Dimot, Aceh Tengah, Indonesia. \\ juliaanoviani@gmail.com
}

\begin{abstract}
COVID-19 as a global pandemic affects various sectors, including education. This study describes students' perceptions of using e-learning in mathematics distance learning during a COVID-19 pandemic. This type of study is descriptive qualitative research. This study involved four students from the Mathematics Education Study Program, Tarbiyah, IAIN Takengon. The researcher gathered the data in this study via an interview process. The interview was conducted by phone since there was a social restriction regulation from the local government. This study states that students experience obstacles while learning mathematics using e-learning during a COVID-19 pandemic. These barriers are classified into three barriers: internal barriers, external barriers, and cross internal and external barriers. Nevertheless, the positive effects are also felt as students have independent learning, confidence while studying, motivation, ease, and flexibility in accessing the e-learning and learning contents. Furthermore, this study recommends that the e-learning design match the learning objectives to minimize the barriers.
\end{abstract}

ARTICLE INFORMATION

\begin{tabular}{lll}
\hline Keywords & & Article History \\
\hline COVID-19 pandemic & & Submitted Jul 24, 2020 \\
E-learning & & Revised Mar 12, 2021 \\
Barriers towards e-learning & Accepted Mar 22, 2021 \\
The positive effect of e-learning & \\
Mathematics learning & & \\
\cline { 1 - 1 } Corresponding Author & & \\
\hline
\end{tabular}

Julia Noviani

IAIN Takengon

Jln. Aman Dimot, Aceh Tengah, Indonesia

Email: juliaanoviani@gmail.com

\section{How to Cite}

Noviani, J. (2021). Perceptions of Mathematics Education Students Toward E-Learning During the Covid-19 Pandemic. Kalamatika: Jurnal Pendidikan Matematika, 6(1), 15-30.

https://doi.org/10.22236/KALAMATIKA.vol6no1.2021pp15-30 


\section{INTRODUCTION}

The COVID-19 outbreak is a threat to all living things on earth. COVID-19 was initially discovered in Wuhan, China, and the World Health Organization (WHO) declared it a pandemic on March 12th, 2020. As of March 14th, 2020, COVID-19 had reached 142,534 cases worldwide, with 5,392 death (WHO, 2020). Every country attempts to prevent the transmission of COVID-19 by applying social distancing, isolation, and quarantine. The pandemic has a massive impact on various sectors of life. During this pandemic, the most affected area is the health sector that causes death to 318,000 worldwide (WHO, 2020). In the economic sector, the pandemic also increases the crisis. Social distancing, self-isolation, and travel restrictions make people losing their jobs, and this situation significantly impacts economics (Nicola et al., 2020). Furthermore, UNESCO revealed that the education sector also impacted; as of March 12th, 46 countries on five different continents have closed schools to prevent the transmission of COVID-19. This condition affects the learning process of nearly 376.9 million children and adolescents worldwide (UNESCO, 2020).

To reduce the COVID-19 cases, the Indonesian government issues social distancing regulation (within social restrictions) in various areas, including education. This regulation makes about 45 million students in Indonesia could not continue their learning activities at schools (Azzahra, 2020). Distance learning or online learning is implemented at any educational level in this case. IAIN Takengon is one of the national campuses in the Central Aceh region that applies online learning. Online learning is a model of distance learning conducted between educators and students due to separated conditions. They could use various media as learning resources in online learning, such as communication and information technology and internet networks.

A modern learning environment will be created by online learning. In two decades, the evolution of information systems has provided alternative ways of teaching online through elearning. Nowadays, e-learning is becoming a learning trend for most students in many countries (Ituma, 2011). E-learning is required by many countries and becomes a core activity in higher education (de Prato, 2013). It could be accessed by students and teachers everywhere without any restrictions, such as time and geographical location. Furthermore, various elearning platforms could be utilized as digital learning media, such as Google Classroom, Canvas, Schoology, Edmodo, and others. 
Mathematics is a unique subject since it consists of symbols and mathematical languages. An effective mathematics e-learning platform must adapt and accommodate the uniqueness of mathematics (Yong Ahn \& Edwin, 2018). Several researchers have also conducted studies on the use of e-learning in teaching mathematics. They stated that e-learning has impacts on students. Mathematics learning using digital technology has advantages, such as make it easy for students to draw graphs, plot, complete complex calculations, apply algebraic transformations, and other uses (Holey \& Noss, 2003). The students' responses indicated that the main advantages of using e-learning in mathematics class are: (a) saving time; (b) breaking the routine; (c) receiving feedback; and (d) engagement (Yamani, 2014). However, e-learning also has disadvantages in terms of understanding new concepts for students. In e-learning, the problem is caused by the lack of interaction between students and teachers. This condition makes it difficult for students to understand new concepts (Abu et al., 2011). Moreover, Yamani (2014) revealed that the disadvantages are (a) lacking physical interaction; (b) getting distracted easily; (c) misusing the internet; and (d) difficulty to master the project at the beginning.

The primary purpose of education is to teach and make students learn. In e-learning, students learn at a distance which causes various difficulties, such as physical problems and mental readiness. The obstacles could extinguish students' enthusiasm for learning (Assareh \& Hosseini Bidokht, 2011). Other barriers are categorized into individual barriers, such as selfmotivation, technological barriers, including access to computers or devices needed, and availability costs (Beamish et al., 2002). Nevertheless, e-learning is one solution that educators must implement to continuity the learning process during the COVID-19 pandemic.

Based on the previous explanation, this study aims to describe students' perceptions of using e-learning during mathematics distance learning. This study is expected to help mathematics instructors use e-learning as a learning medium for students. The study would answer the following research questions:

a. What are students' barriers to learning mathematics using e-learning during a COVID-19 pandemic?

b. What are the positive impacts of learning mathematics using e-learning during a COVID19 pandemic? 


\section{METHOD}

This study is descriptive qualitative research that describes IAIN Takengon mathematics education students' perceptions of mathematics learning using e-learning. The study involved four students in the Mathematics Education Study Program, Tarbiyah, IAIN Takengon. The selection criteria for participants were: (i) mathematics education students enrolled in 2019/2020 even semester, and (ii) mathematics education students studying mathematics online during the COVID-19 pandemic. The researcher gained the data through an interview process. Two experts validated the interview instrument before the interview data was used in this study to be declared valid.

Furthermore, the interview process contained five semi-structured questions. It was conducted by phone because there was a social restriction regulation from the Indonesian government, including isolation and maintaining social distance. Phone interviews were recorded using a recording application to make it easier for the researcher to achieve the objectives of this study. The duration of each interview ranges from 15-20 minutes. Then, the interview results were transcribed and analyzed using appropriate qualitative data analysis techniques.

\section{RESULT AND DISCUSSION}

The interview results show various problems encountered by students in mathematics learning using e-learning during the COVID-19 pandemic. The barriers most likely due to students are not accustomed to using e-learning as a medium for mathematics learning.

\section{Barriers towards E-learning}

Most research participants explained that they had problems while learning mathematics using e-learning during the COVID-19 pandemic. The researcher classifies the barriers into three parts; internal barriers, external barriers, and cross internal and external barriers (Becker et al., 2013; Gamdi \& Samarji, 2016). Internal barriers appear from the students as e-learning users. The variables of internal barriers consist of attitude, pedagogical beliefs in e-learning, and level of competence. Gamdi and Samarji (2016) also stated that internal sources related to technology's attitudes and the competence level of the technology used. 
Furthermore, attitude variables consist of affective, cognitive, and behavior (Asiri et al., 2012). In this study, students have difficulty understanding mathematics content, so that it is classified as a cognitive problem in internal barriers. This statement is strengthened by the excerpt from an interview with one of the research participants.

"I experienced many obstacles when learning mathematics using e-learning. One of them was the lack of knowledge about the mathematics content, then time management problems, the duration of e-learning that was very long, and the assignment during $e$ learning which became more than in face-to-face classes." (Student 1)

Students' habit of mathematics face-to-face learning in the classroom makes it difficult for them to use e-learning. Mathematics is a subject that requires a more in-depth explanation and systematic. Another possibility that causes barriers in mathematics learning using elearning is the language used in mathematics, so students are challenging to understand. In regular classes, lecturers directly convey the mathematics content and explain it clearly on the board, yet these ways are complicated to do in e-learning.

Another student also pointed out that there are problems that they faced while studying mathematics using e-learning.

"I think I did not understand studying mathematics using e-learning, and I did not dare to ask the lecturer about it. It was my first time learning using e-learning, and I felt very nervous and did not accustom to operating. Then my eyes hurt because I stared at the screen for a long time”. (Student 2)

"The internet signal was unstable, and the study duration was not clear. I sometimes did not understand the mathematics content taught online, and it was difficult to ask the lecturer about the learning content. Another obstacle that I felt was my eyes hurt since staring at the laptop for a long time. Sometimes, I also felt dizzy. Furthermore, internet credit is also expensive, and I sometimes run out of the internet credit to access the e-learning classes". (Student 3)

"Difficult to manage the time in online learning, the network was also difficult, and the learning content was hard to be understood. I also found that it was hard to operate the e-learning because I was the first-time-user". (Student 4)

Mathematics contents are complicated to understand by students through e-learning. This condition happens because students of mathematics education in IAIN Takengon had never studied mathematics using e-learning. It makes students shocked and had difficulty in understanding new concepts. Distance learning requires students to study independently in their house, so they could not conduct cooperative learning with their friends, unlike in face- 
to-face classes. Research conducted on students in Ghana regarding distance learning during a COVID-19 pandemic towards 102 respondents (47.7\%) stated that studying alone at home makes it difficult for students to understand the new concepts (Owusu-Fordjour et al., 2020).

However, the lecturer's scaffolding techniques in the face-to-face class help students understand the learning content. Students' learning outcomes increase through scaffolding, and anxiety in mathematics learning decreases significantly by $90.4 \%$. The students also manage to correct and reflect errors in a problem so that scaffolding strategies in the face-toface classes create a positive learning environment for mathematics students (Kusmaryono et al., 2020). Even though students continue to learn during the pandemic, the scaffolding strategies disappear, so that students have difficulty in receiving proper explanations and understanding the new concepts (Owusu-Fordjour et al., 2020).

Another problem classified into internal barriers in this study is that students feel ashamed to ask the lecturer when using e-learning. This condition might happen because initially, students did not understand the lecturer's explanation, felt ashamed to ask questions, and caused a dissolved confusion. One study in Australia expressed that online learning students feel shame because they think that they are incompetent at the task that they have to complete (O’Regan, 2003).

Moreover, health problems also appear in e-learning. Students complained of experiencing eye strain when staring at the mobile phone and laptop screen for too long when using e-learning compared to the face-to-face meeting. Many students have small screen smartphones, usually 4-5 inches, which causes eye strain. This fact is also consistent with research conducted in India that $68.53 \%$ of students experience eye strain when studying using WhatsApp media as a learning tool (Gon \& Rawekar, 2017).

Furthermore, the external barriers come from the outside environment or system. From the interview results, some barriers also come from outside or external, such as poor internet access, lack of training on how to use e-learning, lack of instructional design using e-learning, and lack of campus policy on the use of internet credits. Indonesia's topography with mountainous and archipelago regions urgently needs equitable internet procurement and cellular telecommunications. However, 4G internet coverage is mainly concentrated in Java, prioritizing urban areas rather than rural areas with less population (Khatri, 2019). Figure 1 shows the uneven distribution of internet access per household in all Indonesian provinces. 
This gap makes students from rural areas outside of Java, are disadvantaged. As stated by Azzahra (2020), this fact is in line that unequal internet access is one of the barriers to distance learning in Indonesia. Specifically, many IAIN Takengon students come from isolated rural areas and often have difficulty accessing the internet and e-learning.

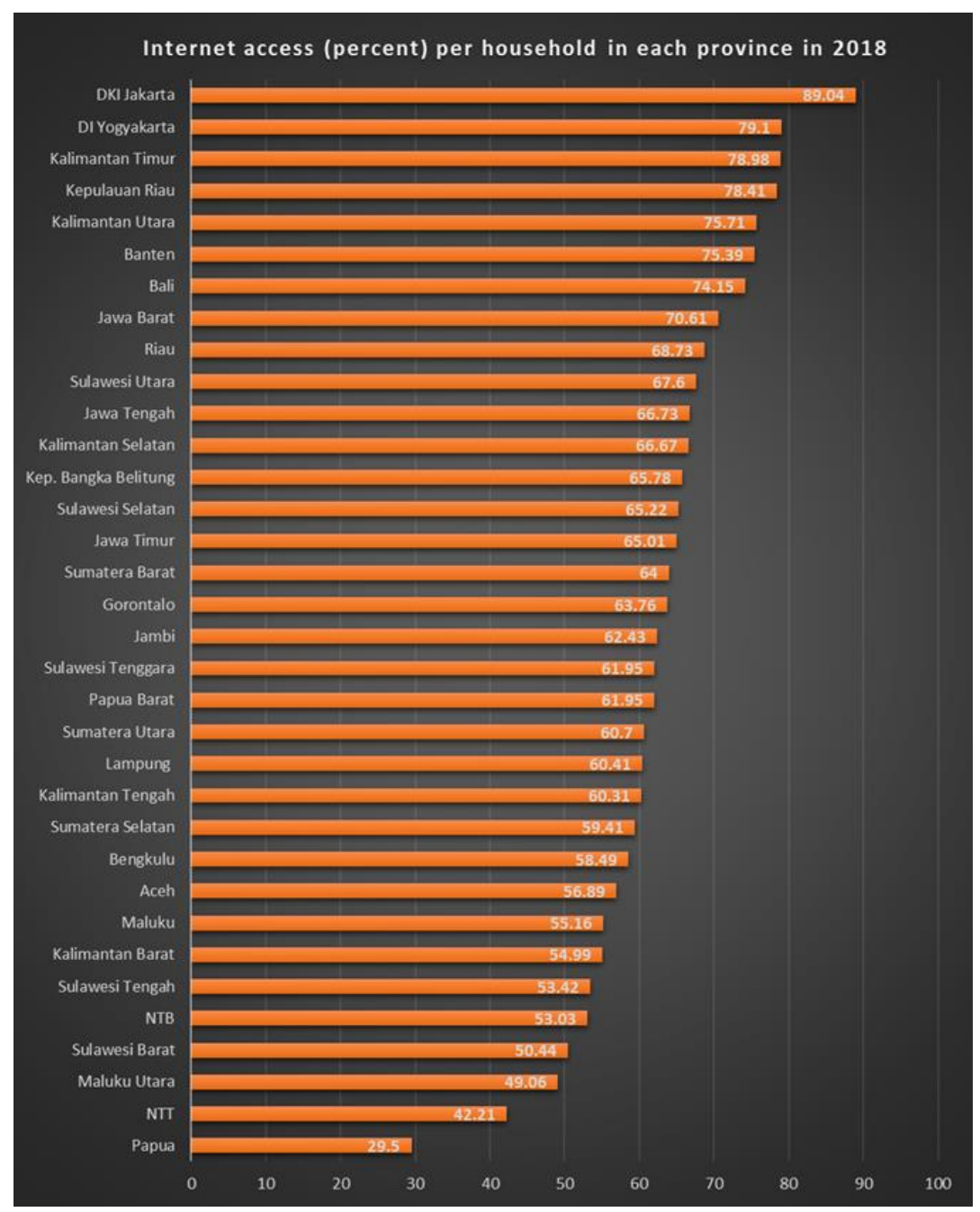

Figure 1. Internet access (percent) per household in each province in 2018 (Azzahra, 2020)

The other barrier is the lack of training in the use of e-learning. This pandemic situation is the first time in mathematics education IAIN Takengon uses e-learning so that the students are not accustomed to using it. Although the students learn how to use e-learning, they do not have the basic skills needed to operate effectively (Ouma et al., 2013). Research conducted by Panda and Mishra (2007) also stated that students' most significant barriers are poor internet access and a lack of training in the use of e-learning. 
The lack of instructional design using e-learning is also a barrier for students. This problem makes it difficult for students to accept and apply the knowledge. The lack of instructional design using e-learning is also experienced by students using e-learning at the University of Saudi Arabia (Gamdi \& Samarji, 2016). Furthermore, the lack of campus policies regarding internet credits towards students is another external obstacle. Students spend many internet credits in using e-learning as a substitute for face-to-face classes. This condition will be better if the campus helps students provide internet credits to achieve successful distance learning. Research conducted by Panda and Mishra (2007) also stated that institutional policies are also a significant problem experienced by students using e-learning.

The other barriers for students are related to the time allocation of learning, while the assignments become overload compared to the situation in a face-to-face classroom. The duration of learning in e-learning is longer than in the face-to-face meeting. It happens because the lecturers do not teach according to the learning duration as in the face-to-face class. It impacts students who have part-time jobs. Furthermore, students also complained about the overload assignments, which lead to stressfulness (Angdhiri, 2020). The overload task is a significant problem for students, so they expect that the e-learning would change into a face-to-face meeting (Ellis et al., 2009). The overload assignments create a poor quality of online learning for students. Thus, the overload assignments which make students exhausted and stressed should be avoided in the design of online learning. Gamdi and Samarji (2016) classified the overload assignments problem as across internal and external barriers.

Table 1. E-Learning Barriers

\begin{tabular}{ll}
\hline Barriers Classification & \multicolumn{1}{c}{ Barriers included in this study } \\
\hline Internal Barriers & - lack of understanding of mathematical content (cognitive) \\
& - lack of social interaction between students and lecturer (pedagogical beliefs) \\
External Barriers & - eye strain when using e-learning continuously (behavior) \\
& - poor internet access \\
& - lack of training using e-learning \\
Cross Internal and External Barriers & - lack of instructional design using e-learning \\
& - lack of campus policy on the use of internet credits \\
& - the duration of learning \\
& - the overload assignments \\
\hline
\end{tabular}

\section{Positive Effects of E-Learning}

Related to the positive effects of studying mathematics using e-learning during the COVID-19 pandemic, students responded that they also feel the positive effects of using elearning during the COVID-19 pandemic.

"I feel independent when learning using e-learning. I try to find supporting resources on the internet or other books to understand lecturers' learning content through $e$ - 
learning. I was also motivated to use e-learning because I try new applications that have never been used, such as Zoom, Webex, Edmodo, and others". (Student 1)

"What I feel when using e-learning is confidence and independence. Due to the pandemic situation that requires us to be isolated at home, my friends and I could not discuss if there is not understood learning content. So, I look for other supporting resources, learn them by myself, and submit assignments confidently. Then, I also learn many new applications Messing Tweaking that I had never used before". (Student 2)

"E-learning is more flexible because we can access it wherever we are. It is more independent learning because the students do not depend on the lecturer's explanation. We are required to try harder so that we understand the mathematical content". (Student 3)

"The positive effect that I feel is the ease of accessing the learning content provided by the lecturer in e-learning. We can open the content anytime in e-learning because the teacher will store it. Then, try various types of e-learning is a new thing for me". (Student 4)

Table 2. Positive Effects of E-learning

\begin{aligned} & \hline \multicolumn{1}{c}{ No } \multicolumn{1}{c}{ Positive effects of e-learning } \\ & \hline 1 Independencelearning \\ & 2 Confidence while studying \\ & 3 Feel motivated to study harder \\ & 4 Students can access e-learning easily and flexibly \\ & 5 Ease of accessing learning content \\ & \hline\end{aligned}

The interview results show that mathematics learning using e-learning also has positive effects. The first positive effect is students feel independent in learning. Students cannot study on campus during the pandemic and must study at home; this case leads students to study independently. Students find appropriate ways to learn by themselves. One study stated that Physics learning using e-learning enhances students' self-reliance efficiency (Shurygin \& Krasnova, 2016). Students also independently search supporting learning content from several resources, such as books and the internet. One way to activate students' independence in learning is by distance learning using e-learning.

Furthermore, students submit assignments independently and regularly while using elearning (Shurygin \& Krasnova, 2016). They can develop learning media independently (Utami \& Saefudin, 2018). E-learning fosters self-directed or independence in students because they use student-centered learning (Zhang et al., 2006).

Studying by using e-learning also increases student confidence. From the interview results, students feel confident in doing the lecturer's tasks and work very carefully to avoid 
mistakes. Wang and friends (2013) found similar results; they reported that e-learning creates an effective learning environment and increases students' confidence. A study at the University of Zayed stated $85 \%$ of students agree that e-learning increases students' confidence and performance (Tubaishat \& Lansari, 2011).

Students also feel motivated to study harder when using e-learning. This finding was consistent with the findings of Wang and friends (2013) that reported that $64 \%$ of students feel motivated to learn using e-learning. Research conducted by Harandi (2015) also stated that students are more likely to be motivated when learning by implementing e-learning. It is because students can explore new applications during distance learning. They learn about new applications that they have never used, such as Zoom, Webex, Edmodo, and others. Zhang and friends (2006) emphasized that e-learning makes students explore new things.

Another positive thing found by students when learning mathematics by using elearning is students can also access e-learning anywhere flexibly. E-learning can be accessed by students anywhere and anytime, making it easier for students to learn. Each student can freely choose a comfortable place to learn when studying using e-learning and choose the appropriate time to repeat studying the learning content (Pei Zhao, Sara Sintonen, et al., 2015).

The ease of accessing learning content that lecturers have provided is also a positive effect of e-learning. E-learning provides unlimited access to the subject matter (Zhang et al., 2006). Furthermore, Khan (2010) argued that e-learning is innovative, interactive, and could facilitate anyone who wants to learn anywhere, anytime by utilizing available technological facilities.

Moreover, learning mathematics during the pandemic using e-learning has its challenges; it has obstacles and advantages. From the research results, students also learn mathematics with new and fun things by using e-learning. Mathematics education students at IAIN Takengon had never learned using e-learning before the pandemic, so this kind of learning provides an entirely new experience for them. E-learning will make pedagogical shifts to less formal teaching mathematics methods entertaining and engaging rather than rigorous and conventional (Mulenga \& Marbán, 2020). However, students also feel the most crucial obstacle which they do not understand the learning content taught through e-learning. This condition is most likely caused by the symbols and specific languages used in mathematics so that students are challenging to understand. There are challenges, such as the 
limitations of writing mathematical symbols and the learning management system's and multimedia software's basic capabilities for supporting online learning (Irfan et al., 2020). The difficulty of communicating with students using mathematical language through e-learning could be the reason for difficulties in understanding mathematics learning content.

To overcome the problems, teachers and lecturers must continue to learn and encourage interaction and online discussion. The efforts are significant because they can influence students' progress in learning mathematics and develop their mathematical skills. They can also be utilized as a teacher's assessment tool to design mathematics teaching and learning that facilitates mathematical conversation under any circumstances (Wahyuningrum \& Latifah, 2020).

\section{CONCLUSION}

COVID-19 pandemic affects various sectors, including education. This study describes students' perceptions of studying mathematics using e-learning in distance learning during a COVID-19 pandemic. The results of this study indicate that students experience barriers when learning mathematics using e-learning. These barriers are classified into three parts, (1) internal barriers, namely lack of understanding of mathematical content, lack of social interaction between students and lecturer, and eye strain when using e-learning continuously, (2) external barriers include poor internet access, lack of training using e-learning, lack of instructional design using e-learning, and lack of campus policy on the use of internet credits, and (3) cross internal and external barriers include the duration of learning and overload assignments. Although students experience barriers while learning using e-learning, students also feel the positive effects of e-learning during distance learning. The results of this study state the positive effects experienced by students are (1) independence learning, (2) confidence while studying, (3) students are motivated when using e-learning, (4) e-learning can be accessed quickly and flexibly, (5) ease of accessing learning content. Therefore, this study recommends that the implementation of mathematics learning using e-learning have to pay attention to appropriate learning objectives design so that the obstacles could be minimized or even not occur.

\section{REFERENCES}

Abu, I., Alkhateeb, F., Al, E., Alsmadi, I., \& Samarah, S. (2011). Annotations, Collaborative 
Tagging, and Searching Mathematics in E-Learning. International Journal of Advanced Computer Science and Applications, 2(4), 30-39. https://d oi.org/10.14569/ijacsa.2011.020404

Angdhiri, R. P. (2020). Challenges of home learning during a pandemic through the eyes of a student. Jakarta Post. https://www.thejakartapost.com/life/2020/04/11/challenges-ofhome-learning-during-a-pandemic-through-the-eyes-of-a-student.html

Asiri, M. J., Mahmud, R. B., Abu Bakar, K., \& Mohd Ayub, A. F. Bin. (2012). Factors Influencing the Use of Learning Management System in Saudi Arabian Higher Education: A Theoretical Framework. Higher Education Studies, 2(2), 125-137. https://doi.org/10.5539/hes.v2n2p125

Assareh, A., \& Hosseini Bidokht, M. (2011). Barriers to E-teaching and E-learning. Procedia Computer Science, 3, 791-795. https://doi.org/10.1016/j.procs.2010.12.129

Azzahra, N. F. (2020). Mengkaji Hambatan Pembelajaran Jarak Jauh di Indonesia di Masa Pandemi Covid-19. Center for Indonesians Policy Studies, 19(2), 1-9.

Becker, K., Newton, C., \& Sawang, S. (2013). A learner perspective on barriers to e-learning. Australian Journal of Adult Learning, 53(2), 211-233.

de Prato, G. (2013). IIC Annual Conference. Info, 15(3), 63-68. https://doi.org/10.1108/info.2013.27215caa.003

Ellis, R. A., Ginns, P., \& Piggott, L. (2009). E-learning in higher education: Some key aspects and their relationship to approaches to study. Higher Education Research and Development, 28(3), 303-318. https://doi.org/10.1080/07294360902839909

Gamdi, M. A. Al, \& Samarji, A. (2016). Perceived Barriers towards e-Learning by Faculty Members at a Recently Established University in Saudi Arabia. International Journal of Information and Education Technology, 6(1), 23-28. https://doi.org/10.7763/ijiet.2016.v6.652

Gon, S., \& Rawekar, A. (2017). 8454-16768-3-PB.pdf. 4(June), 19-25. 
https://doi.org/10.18311/mvpjms/2017/v4i1/8454

Harandi, S. R. (2015). Effects of e-learning on Students' Motivation. Procedia - Social and Behavioral Sciences, $\quad$ 181(October), 423-430. https://doi.org/10.1016/j.sbspro.2015.04.905

Irfan, M., Kusumaningrum, B., Yulia, Y., \& Widodo, S. A. (2020). Challenges During the Pandemic: Use of E-Learning in Mathematics Learning in Higher Education. Infinity Journal, 9(2), 147. https://doi.org/10.22460/infinity.v9i2.p147-158

Ituma, A. (2011). An evaluation of students' perceptions and engagement with e-learning components in a campus-based university. Active Learning in Higher Education, 12(1), 57-68. https://doi.org/10.1177/1469787410387722

Khan, B. (2010). The Global e-Learning Framework. Stride Handbook 8, 42-51. http://technologysource.org/article/336/

Kusmaryono, I., Gufron, A. M., \& Rusdiantoro, A. (2020). Effectiveness of Scaffolding Strategies in Learning Against Decrease in Mathematics Anxiety Level. Jurnal Matematika Dan Pendidikan Matematika, 4, 13-22. https://doi.org/https://doi.org/10.25217/numerical.v4i1.770

Mulenga, E. M., \& Marbán, J. M. (2020). Is covid-19 the gateway for digital learning in mathematics education? Contemporary Educational Technology, 12(2), 1-11. https://doi.org/10.30935/cedtech/7949

Nicola, M., Alsafi, Z., Sohrabi, C., Kerwan, A., Al-Jabir, A., Iosifidis, C., Agha, M., \& Agha, R. (2020). The Socio-Economic Implications of the Coronavirus and COVID-19 Pandemic: A Review. International Journal of Surgery, 78(March), 185-193. https://doi.org/10.1016/j.jisu.2020.04.018

O’Regan, K. (2003). Emotion and E-learning. Journal of Asynchronous Learning Network, 7(3), 78-92. https://doi.org/10.24059/olj.v7i3.1847

Ouma, G., Awuor, F., \& Kyambo, B. (2013). E-Learning Readiness in Public Secondary 
Schools in Kenya. European Journal of Open, Distance and e-Learning, 16(2), 97110. http://www.eurodl.org/materials/contrib/2013/Ouma_et_al.pdf

Owusu-Fordjour, C., Koomson, C. K., \& \& Hanson, D. (2020). The impact of COVID-19 on the learning-the perspective of the Ghanaian student. European Journal of Education Studies, 7(3), 88-101. https://doi.org/10.5281/zenodo.3753586

Panda, S., \& Mishra, S. (2007). E-Learning in a Mega Open University: Faculty attitude, barriers, and motivators. Educational Media International, 44(4), 323-338. https://doi.org/10.1080/09523980701680854

Pei Zhao, Sara Sintonen, H. K., Currie, K. L., \& J.Courduff. (2015). The pedagogical functions of arts and cultural-heritage education with ICTs in museums. International Journal of Instructional Technology and Distance Learning, 7.

Shurygin, V. Y., \& Krasnova, L. A. (2016). Electronic learning courses as a means to activate students' independent work in studying physics. International Journal of Environmental and Science Education, 11(8), 1743-1751. https://doi.org/10.12973/ijese.2016.551a

Tubaishat, A., \& Lansari, A. (2011). Are Students Ready to Adopt E-Learning ? A Preliminary E-readiness Study of a University in the Gulf Region. International Journal of Information and Communication Technology Research, 1(5), 210-215. http://citeseerx.ist.psu.edu/viewdoc/download?doi=10.1.1.302.302\&rep=rep1\&type=p df

Utami, N. W., \& Saefudin, A. A. (2018). Comparative Study of Learning Using E-Learning and Printed Materials on Independent Learning and Creativity. Journal of Physics: Conference Series, 954(1). https://doi.org/10.1088/1742-6596/954/1/012004

Wahyuningrum, A. S., \& Latifah, T. (2020). Investigating mathematical conversation in remote learning of mathematics during the covid-19 pandemic. Jurnal Riset Pendidikan Matematika, 7(2), 148-162.

Wang, J., Wayne Yu, W.-C., \& Wu, E. (2013). Empowering Mobile Assisted Social E- 
Learning: Students' Expectations and Perceptions. World Journal of Education, 3(2). https://doi.org/10.5430/wje.v3n2p59

WHO. (2020). Coronavirus disease 2019 (COVID-19) Situation Report - 54. WHO Bulletin, 2019(March), 2633. https://doi.org/10.1001/jama.2020.2633

Yamani, H. A. (2014). E-learning in Saudi Arabia. Journal of Information Technology and Application in Education, 3(4), 169. https://doi.org/10.14355/jitae.2014.0304.10

Yong Ahn, J., \& Edwin, A. (2018). An e-Learning Model for Teaching Mathematics on an Open Source Learning Platform dynamic and interactive content, e-learning platform, learning theory, mathematical learning model An e-Learning Model for Teaching Mathematics on an Open Source Learning Pla. International Review of Research in Open and Distributed Learning, 19(5).

Zhang, D., Zhou, L., Briggs, R. O., \& Nunamaker, J. F. (2006). Instructional video in elearning: Assessing the impact of interactive video on learning effectiveness. Information and Management, 43(1), 15-27. https://doi.org/10.1016/j.im.2005.01.004 
